\title{
In Vitro Cytotoxic Activity of Chelidonium majus extract using Different Types of Cell Lines
}

\author{
Yasir B. Fadhil*, Khulood W. Alsammarraie, Nedhal Abdul Mohaimen and \\ Zainab Yasin Mohammed
}

Department of Biotechnology, College of Science, Al-Nahrain University, Baghdad, Iraq

*Corresponding author

\begin{tabular}{l} 
Key w or d s \\
$\begin{array}{l}\text { Chelidonium majus, } \\
\text { Cell culture, MTT } \\
\text { assay }\end{array}$ \\
\hline Article Info \\
$\begin{array}{l}\text { Accepted: } \\
\text { 14 December } 2017 \\
\text { Available Online: } \\
\text { 10 January } 2018\end{array}$ \\
\hline
\end{tabular}

\section{Introduction}

Chelidonium majus L. (poppy family), known as greater celandine, the plant grows wild in parts of Asia, North America, Southern and Central Europe (Colombo and Bosisio, 1996).

Due to their notable pharmacological effects, Ch. majus is widely used in traditional and modern medicine for the treatment of liver diseases, gastrointestinal tract, and there are also some data which demonstrated the use of this herb for the prevention and treatment of
A B S T R A C T

Cancer is becoming a health problem in all over the world, searching for anticancer therapy from plants natural products has been one of the sustainers of cancer chemotherapy approximately for the past half a century. Chelidonium majus (Poppy Family) is a plant which is distributed in nature and has been used as a traditional medicine. The plant extract showed high content of alkaloids which revealed cytotoxic effect in a cell type and dose dependent way. Cytotoxic analysis of alkaloids extract from Chelidonium majus using MTT assay on different cell lines. 100 grams of the plant material powdered and extracted with methanol using Soxhlet installation, the extract was subjected farther more for acid-base extraction and purification with chloroform. Cytotoxic effect of total alkaloid was estimated using MTT-assay manufacturer's instructions. The total alkaloid extract of $C$. majus exhibited remarkably significant cytotoxic effect on (Hep-G2, MCF-7 and A-549) cell lines in a dose dependent and cell type dependent manner. The extract illustrated considerable cytotoxic activity against various types of cancer cell lines in vitro. The antitumor activity was extremely efficient in a dose dependent manner it displayed decreased viability of tumor cells. 
(Kokoska et al., 2002), immunomodulatory (Song et al., 2002), antitumor, choleretic, hepatoprotective, analgesic (Gilca et al., 2010), which are in concordance with the traditional uses of C. majus.

Different alkaloids of $C$. majus have the following activities that might be responsible for its anticancer effect:

Reduced telomerase activity by chelidonine (Noureini and Wink, 2009),

Cancer cell death by apoptosis (Noureini and Wink, 2009; Habermehl et al., 2006; Philchenkov et al., 2008),

And blister cell death (Philchenkov et al., 2008),

Arrest of mitosis by inhibition (Noureini and Wink, 2009).

A number of studies suggest that Ukrain TM (an anticancer drug whose major components are $C$. majus alkaloids chelidonine, sanguinarine, chelerythrine, protopine, and allocryptine) (Habermehl et al., 2006) exerts multiple selective effects on cancer cells:

Cytotoxic effects on cancer cells without negative effects on normal cells (Hohenwarter et al., 1992);

Radio-sensitizing effects on cancer cells, but radio-protective effects on normal cells (Cordes et al., 2002).

\section{Materials and Methods}

\section{Preparation of plant material and extract}

The plant material extraction and purification followed (Bugatti et al., 1991) and (Ramawat and Merollin, 2007) in brief: The plant material was collected from Botanic Planet a store of herbs and natural product in (Brampton, Ontario, Canada) as grinded dried parts (aerial part only). 100 grams of the plant material powdered by using grinder and packed loosely in thimble, the plant extracted with organic solvent $85 \%$ methanol $(500 \mathrm{ml})$ using a Soxhlet installation for $24 \mathrm{hrs}$.

The extract then half evaporated and then combined in beaker. Using sulphuric acid the extract $\mathrm{pH}$ reduced to value $(\mathrm{pH}$ 2) (Checked by litmus paper), then extracted in a separatory funnel with $100 \mathrm{ml}$ chloroform. Both phases (A for aqueous phase, B for nonpolar phase) were collected separately.

The aqueous phase (A) basified by ammonium hydroxide until the $\mathrm{pH}$ reached to the value (pH 9) (Checked by litmus paper) and extracted again with organic solvent chloroform in separatory funnel, the two phases were collected separately $(\mathrm{A}+$ for aqueous phase, $\mathrm{B}+$ for non-polar phase). $\mathrm{A}+$ phase was extracted again with chloroform till Dragendorff's test was negative. A, B and $\mathrm{B}^{+}$ phases were concentrated by evaporation then dried and calculated for total Alkaloid. During extraction and purification steps $\left(\mathrm{A}, \mathrm{A}^{+}, \mathrm{B}\right.$ and $\mathrm{B}^{+}$phases) samples were collected and estimated for alkaloid by using Dragendorff's and Mayer's test (Figure 4).

\section{Cell culture}

Hep-G2 (Human liver cancer cell line), MCF7(Breast cancer cell line) and A-549 (Human alveolar adenocarcinomic cell line) were collected from National Center for Cell Science (NCCS Pune / India). The cells were maintained in RPMI-1640 medium which supplemented with $10 \%$ fetal bovine serum, $10 \mathrm{ug} / \mathrm{ml}$ Ciprofloxacin all from (Sigma, India). Cells were incubated at $37^{\circ} \mathrm{C}$ in an atmosphere of $5 \% \mathrm{CO}^{2}$ and absolute humidity. Cell number and viability were determined using ethidium bromide. 


\section{Cytotoxicity study}

\section{MTT assay}

Cytotoxic effect of total alkaloid was estimated using MTT-assay according to manufacturer's instructions (HiMedia, India) (http://himedialabs.com/TD/CCK003.pdf) in brief: The cell suspension seeded in a 96-well plate and at required cell density (20,000 cells per well), without the test agent and then incubated to grow and adhere for about 12 hours. After incubation the plate were taken out and examined under inverted microscope to ensure cells adherent, appropriate concentrations of the extracted total alkaloid were added $(5,50,100,150$ to $200 \mu \mathrm{g} / \mathrm{mL})$ and then incubated for $24 \mathrm{hrs}$ at $37^{\circ} \mathrm{C}$ in $5 \% \mathrm{CO} 2$ atmosphere.

After the incubation period, $10 \%$ of MTT reagent $(5 \mathrm{mg} / \mathrm{ml})$ were added to a final concentration of total volume. The plates were wrapped with aluminum foil to avoid exposure to light and incubator and incubated for 3 hours.

During that time, metabolically active viable cells reduced yellow, MTT was reduced to purple formazan, due to activity of mitochondrial dehydrogenase. The MTT reagent was carefully removed and then $100 \mu \mathrm{l}$ of solubilisation solution dimethylsulfoxide (DMSO) was added to each well. A gentle shake was done to enhance dissolution. Occasionally, pipetting up and down was required to completely dissolve the MTT formazan crystals especially in dense cultures. The absorbance were values read by ELISA reader at $570 \mathrm{~nm}$ and $630 \mathrm{~nm}$ which was used as reference wavelength The percentage of inhibition was calculated according to the following equation;

Inhibition $\%=100-[$ (optical density of test wells/optical density of control wells)] $\times 100$.
Experiment controls were medium control without cells, medium with cells but without total alkaloid (negative control) and medium with cells treated with berberine (positive control).

\section{Statistical analysis}

The Statistical Analysis System- SAS (2014) program was used to analyse effect of different concentration for studying parameters (viability \%). Least significant difference -LSD test (ANOVA) was used to significantly compare between means in this study (SAS, 2014).

\section{Results and Discussion}

\section{Hep-G2 human hepatocyte carcinoma}

In Hep-G2 the percentage of viability was clarified in (Table 1) results were presented as mean \pm SE. for non-treated cells the percentage was $100 \%$ at $24 \mathrm{hrs}$ of incubation. The percentage of viability started to decrease at concentration 150, 300, 450, 600 and 750 $\mu \mathrm{g} \mathrm{ml}^{-1}$ to reach $77.67 \pm 1.52,51.34 \pm 2.34$, $5.73 \pm 0.52,1.17 \pm 0.44$, and $0.59 \pm 0.17 \%$ respectively at $24 \mathrm{hrs}$ of incubation. Cell proliferation was significantly decreased following treatment with the $C$. majus extract (Figure 1) in a concentration dependent manner (Figure 5) $(\mathrm{P}<0.01)$. The IC50 was observed at $282.86 \mu \mathrm{g} / \mathrm{ml}$ after $24 \mathrm{hrs}$ of treatment.

\section{MCF-7 human breast cancer}

The viability of MCF-7 clarified in (Table 2) results were presented as mean $+\mathrm{SE}$. for nontreated cells the percentage was $100 \%$ at $24 \mathrm{hrs}$ of incubation. The percentage of viability started to decrease at concentration 150, 300, 450,600 and $750 \mu \mathrm{g} \mathrm{ml}-1$ to reach $84.12 \pm$ $3.45,76.04 \pm 3.22,64.55 \pm 5.09,50.21 \pm 2.66$, and $29.92 \pm 0.86 \%$ at $24 \mathrm{hrs}$ of incubation. 
Table.1 Effect of concentration in viability // Cell line: Hep-G2

\begin{tabular}{|c|c|}
\hline Concentration $(\mu \mathrm{g} / \mathrm{ml})$ & Mean \pm SE of Viability $(\%)$ \\
\hline Control & $100.00 \pm 0.00 \mathrm{a}$ \\
\hline 150 & $77.67 \pm 1.52 \mathrm{~b}$ \\
\hline 300 & $51.34 \pm 2.34 \mathrm{c}$ \\
\hline 450 & $5.73 \pm 0.52 \mathrm{~d}$ \\
\hline 600 & $1.17 \pm 0.44 \mathrm{~d}$ \\
\hline 750 & $0.59 \pm 0.17 \mathrm{~d}$ \\
\hline LSD value & \\
\hline P-value & \\
\hline
\end{tabular}

** $(\mathrm{P}<0.01)$. Means having the different letters in same column differed significantly.

Table.2 Effect of concentration in viability // Cell line: MCF-7

\begin{tabular}{|c|c|}
\hline Concentration $(\mu \mathrm{g} / \mathrm{ml})$ & Mean \pm SE of Viability $(\%)$ \\
\hline Control & $100.00 \pm 0.00 \mathrm{a}$ \\
\hline 150 & $84.12 \pm 3.45 \mathrm{~b}$ \\
\hline 300 & $76.04 \pm 3.22 \mathrm{c}$ \\
\hline 450 & $64.55 \pm 5.09 \mathrm{~d}$ \\
\hline 600 & $50.21 \pm 2.66 \mathrm{e}$ \\
\hline 750 & $29.92 \pm 0.86 \mathrm{f}$ \\
\hline LSD value & $6.882 * *$ \\
\hline P-value & 0.0001 \\
\hline
\end{tabular}

** $(\mathrm{P}<0.01)$. Means having the different letters in same column differed significantly.

Table.3 Effect of concentration in viability // Cell line: A-549

\begin{tabular}{|c|c|}
\hline Concentration $(\mu \mathrm{g} / \mathrm{ml})$ & Mean \pm SE of Viability $(\%)$ \\
\hline Control & $100.00 \pm 0.00 \mathrm{a}$ \\
\hline 150 & $53.09 \pm 0.87 \mathrm{~b}$ \\
\hline 300 & $36.42 \pm 3.11 \mathrm{c}$ \\
\hline 450 & $3.06 \pm 0.18 \mathrm{~d}$ \\
\hline 600 & $1.07 \pm 0.09 \mathrm{~d}$ \\
\hline 750 & $0.85 \pm 0.09 \mathrm{~d}$ \\
\hline LSD value & $7.924 * *$ \\
\hline P-value & 0.0001 \\
\hline
\end{tabular}

$* *(\mathrm{P}<0.01)$. Means having the different letters in same column differed significantly 
Fig.1 Cytotoxic effect of $C$. majus on Hep-G2 cell line

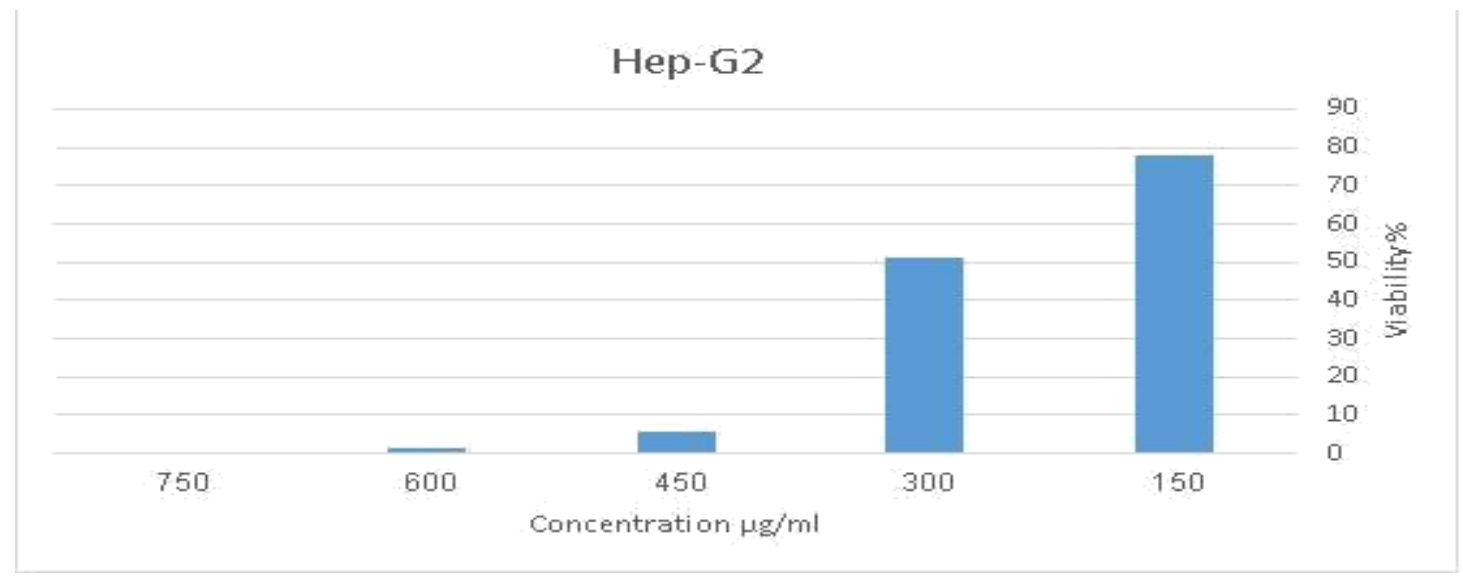

Fig.2 Cytotoxic effect of C. majus on MCF-7 cell line

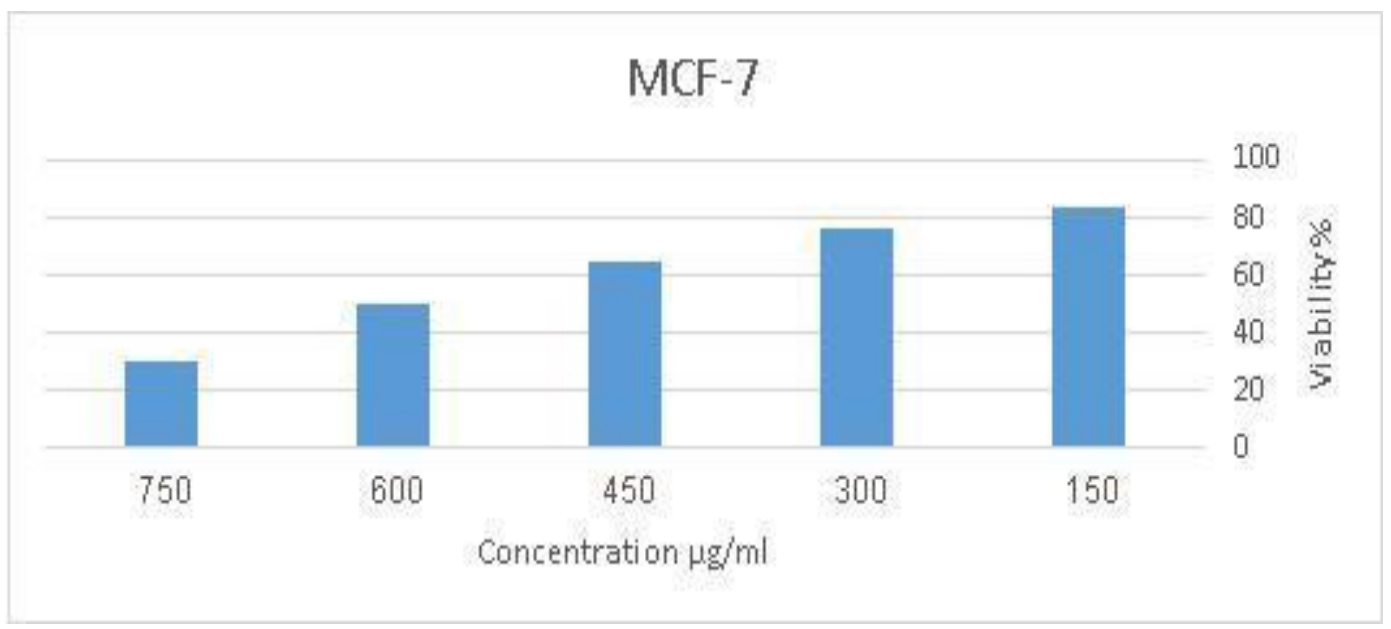

Fig.3 Cytotoxic effect of C. majus on A-549 cell line

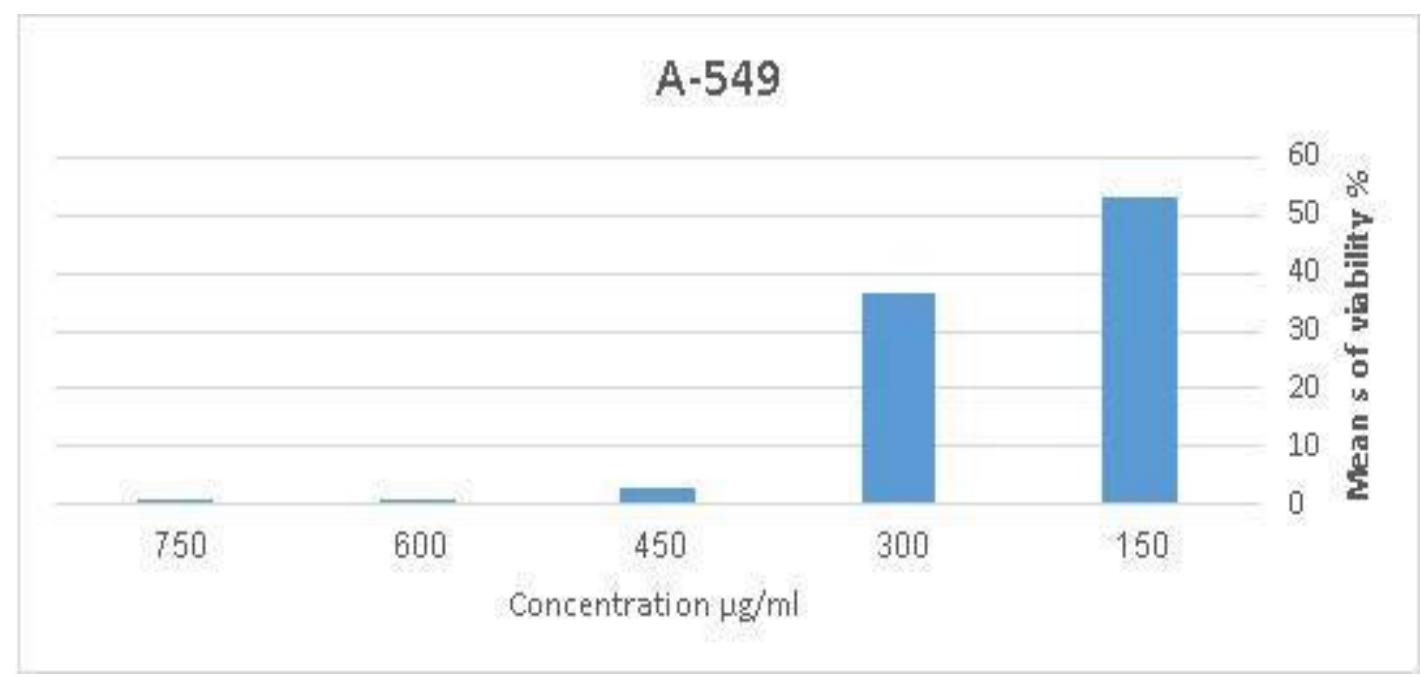


Fig.4 Estimation of total alkaloid by Dragendorff's (A) and Mayer's (B) reagent

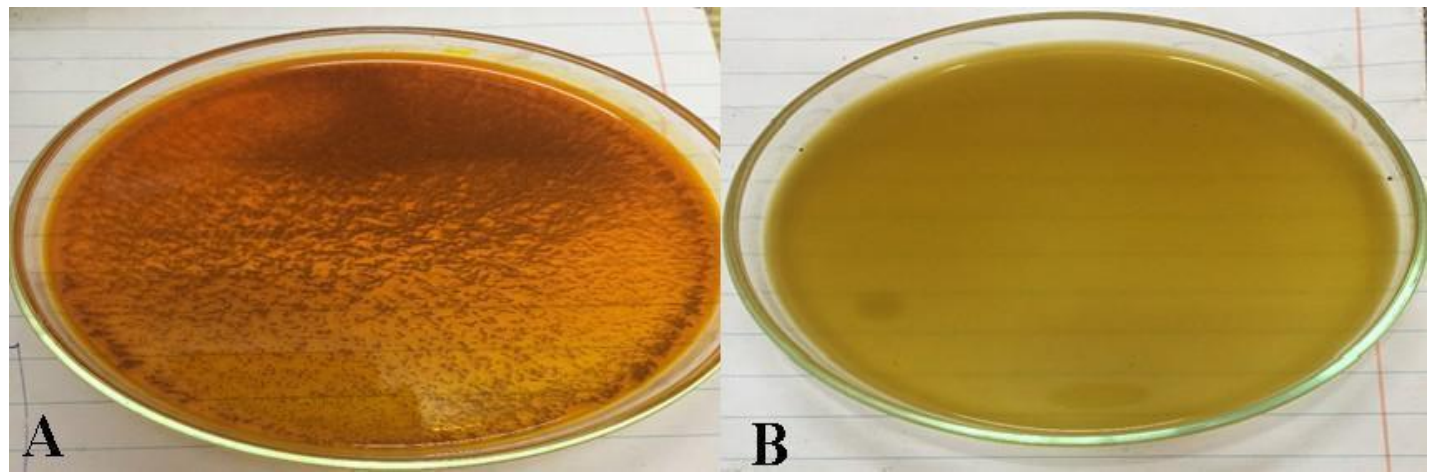

Fig.5 Inverted microscopy image of Hep-G2 treated and untreated (control) cell lines respectively. Morphology was visualized and photographed under light microscope (magnification, x100)
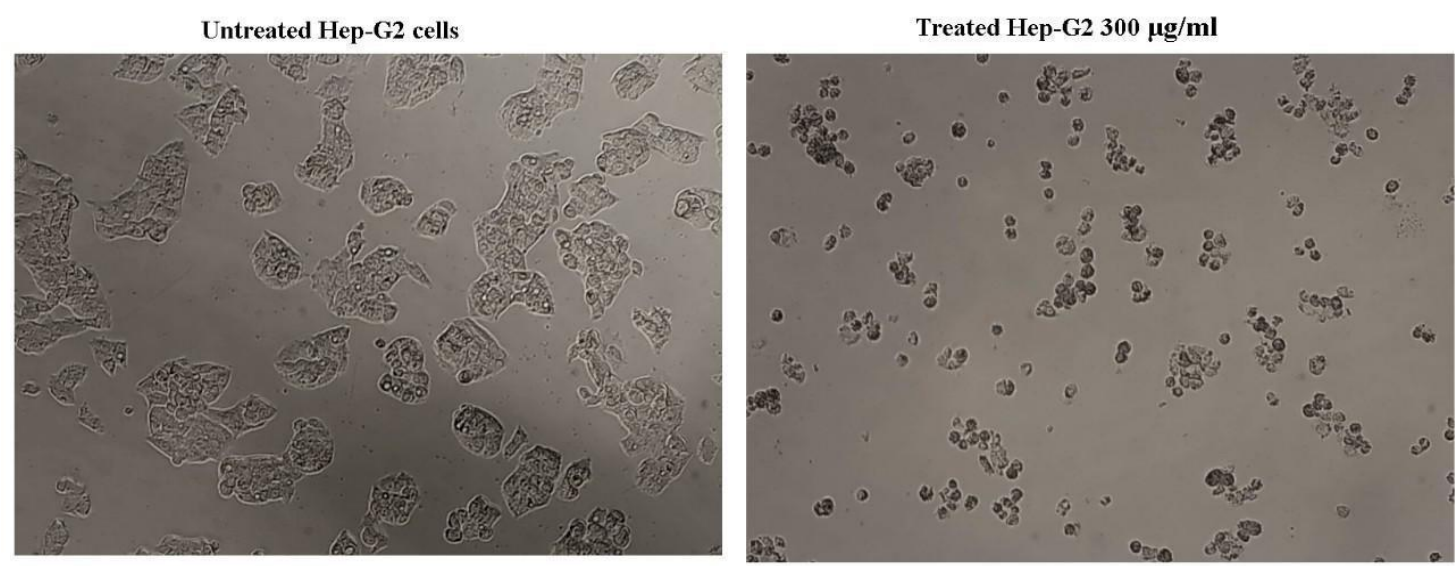

Fig.6 Inverted microscopy image of MCF-7 treated and untreated (control) cell lines respectively. Morphology was visualized and photographed under light microscope

(magnification, $\mathrm{x} 100$ )
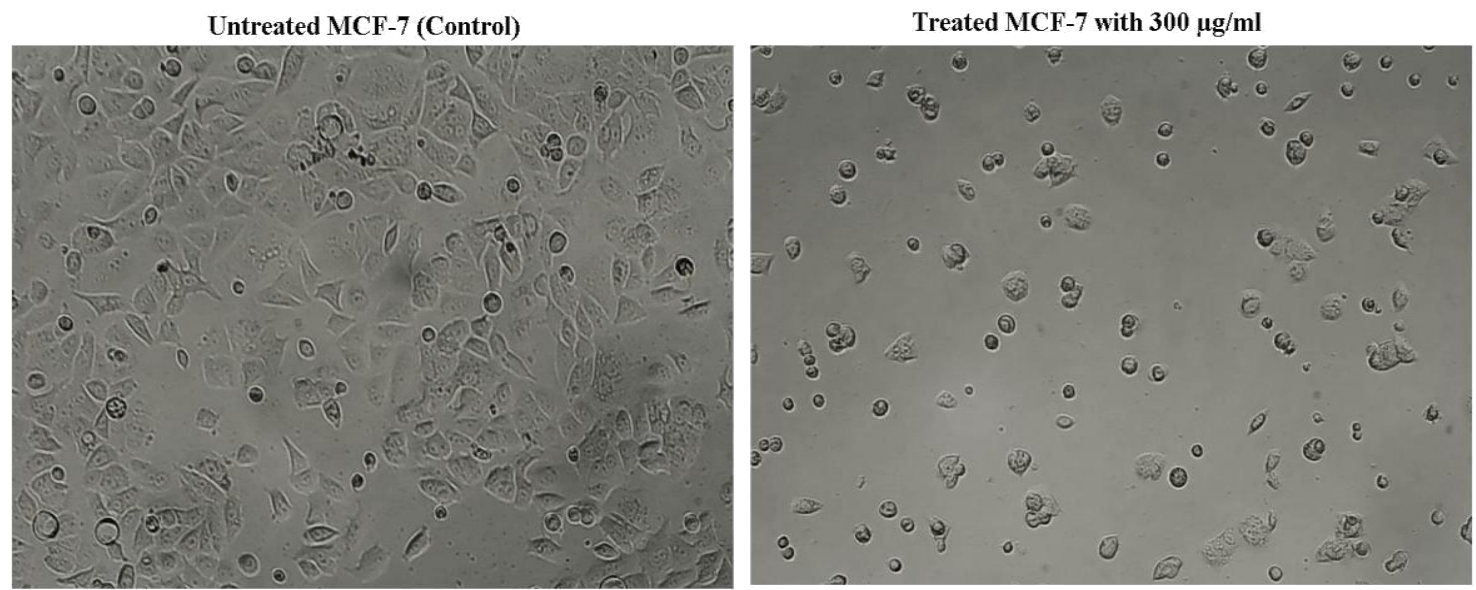
Fig.7 Inverted microscopy image of Hep-G2 treated and untreated (control) cell lines respectively. Morphology was visualized and photographed under light microscope

(magnification, $\mathrm{x} 100$ )

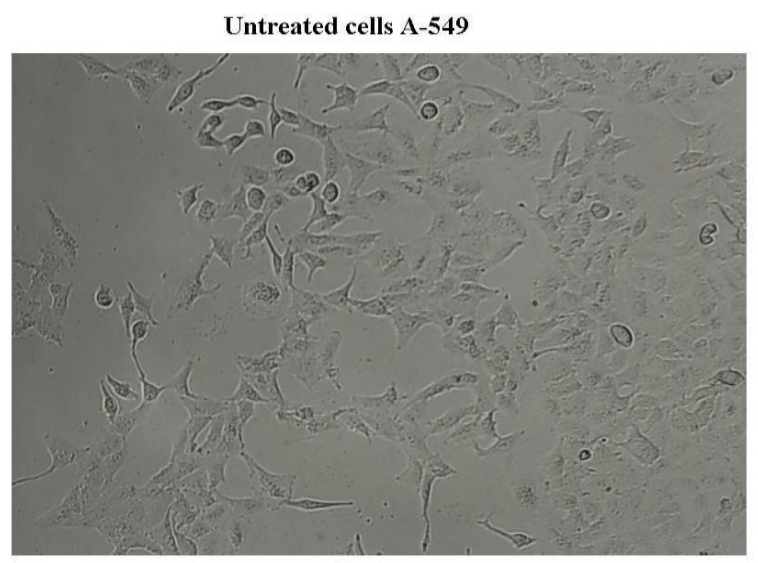

Cell proliferation was significantly decreased following treatment with the $C$. majus extract (Figure 2) in a concentration dependent manner (Figure 6) $(\mathrm{P}<0.01)$. The IC50 was observed at $570.879 \mu \mathrm{g} / \mathrm{ml}$ after $24 \mathrm{hrs}$ of treatment.

\section{A-549 Human Lung Carcinoma}

The percentage of growth inhibition for A549 was clarified in (Table 3) results are presented as mean $\pm \mathrm{SE}$. for non-treated cells the percentage was $100 \%$ at $24 \mathrm{hrs}$ of incubation. The percentage of viability started to decrease at concentration $150,300,450,600$, and $750 \mu \mathrm{g} \mathrm{ml}-1$ to reach $53.09 \pm 0.87,36.42$ $\pm 3.11,3.06 \pm 0.18,1.07 \pm 0.09$, and $0.85 \pm$ $0.09 \%$ at $24 \mathrm{hrs}$ of incubation.

Cell proliferation was notably decreased following treatment with the C. majus (Figure $3)$ extract in a concentration dependent manner (Figure 7) $(\mathrm{P}<0.01)$. The IC50 was observed at $172.12 \mu \mathrm{g} / \mathrm{ml}$ after $24 \mathrm{hrs}$ of treatment.

In association with other studies done by (ZareShahneh et al., 2013) which showed the cytotoxic effect of the crude methanolic
Treated cells A-549 with $300 \mu \mathrm{g} / \mathrm{ml}$

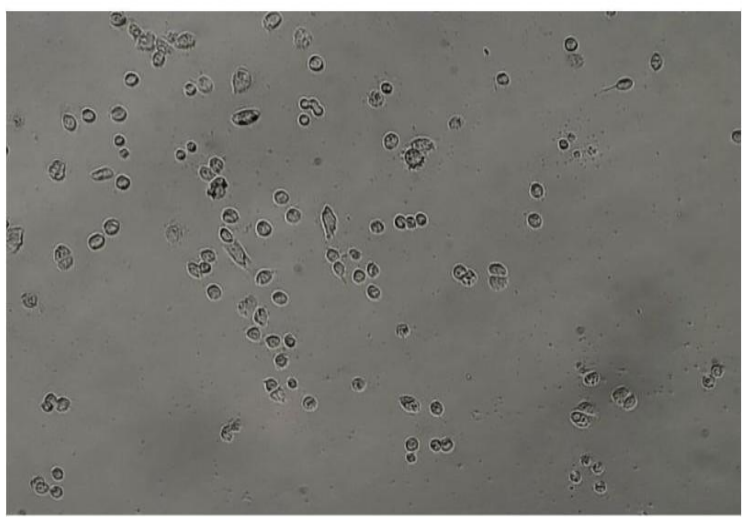

extract of Chelidonium majus were probed in vitro using MTT assay. MTT results surfaced that cytotoxic effect alongside NonHodgkin's B-cell lymphoma (Raji), human leukemic monocyte lymphoma (U937), human acute myelocytic leukaemia (KG-1A), human breast carcinoma (MCF-7 cells), and human Prostate Cancer (PC3) cell lines in a dose-dependent manner. Milena Deljanin et al., (2016) demonstrated that $C$. majus extract decreased viability of tumor cells. Treatment with C. majus extract culminated in time- and dose-dependent proliferation in cytotoxicity. The cytotoxic effect of the extract on MCF-7 asserted IC50 value which was $179,35 \mu \mathrm{g} / \mathrm{ml}$.

In this paper the results showcased cytotoxic effect of extracted alkaloid on different type of cell line. Where it appeared that toxicity was in a dose dependent manner as well as type dependent manner, which might be due to cell type and sensitivity to the extract.

\section{Acknowledgments}

We are appreciating all the people associated with the work and it was privilege that we have had the great opportunity and pleasure to work with during the research. Authors would 
like to acknowledge Biotechnology research center of Al-Nahrain University and Stellixir Biotech Company for their cooperation in accomplishing the study.

\section{Conflict of interest}

Authors declare no conflict of interest.

\section{Funding}

There is no funding source for this research.

\section{References}

Aljuraisy YH, Mahdi NK, Al-Darraji MNJ. Cytotoxic effect of Chelidonium majus on cancer cell. Al-Anbar journal of Veterinary Sciences 2012; 5(1):85-90.

Barreto MC, Pinto RE, Arrabaca JD, Pavão ML. Inhibition of mouse liver respiration by Chelidonium majus isoquinoline alkaloids. Toxicology Letters 2003; 146: 37-47. doi: 10.1016/j.toxlet.2003.09.007

Bugatti, C., Colombo, M. L., Tome, F., 1991 A New Method for Alkaloid Extraction from Chelidonium majus L, Phytochem. Anal., 2:65-67. doi:10.1002/pca. 2800020204

Colombo M, and Bosisio E. Pharmacological activities of Chelidonium majus L. (Papaveraceae) Pharm Res. 1996; 33:127-134. doi:10.1006/phrs.1996.0019

Cordes N, Plasswilm L, Bamberg M, Rodemann HP: Ukrain, an alkaloid thiophosphoric acid derivative of Chelidonium majus L. protects human fibroblasts but not human tumor cells in vitro against ionizing radiation. Int $\mathrm{J}$ Radiat Biol 2002; 78(1):17-27. doi:10.1080/09553000110089991.

De Melo JG, Santos AG, de Amorim ELC, do Nascimento SC, de Albuquerque UP. Medicinal plant used as antitumor agents in Brasil: an ethnobotanical approach. Evid Based Complement Alternat Med. 2011; 2011. doi:10.1155/2011/365359

Deljanin M, Nikolic M, Bask ic D, Todorovic D, Djurdjev ic P, Zaric M, Stankovic M, Todorovic M, Avramovic D, Popovic S. Chelidonium majus crude extract inhibits migration and induces cell cycle arrest and apoptosis in tumor cell lines. J Ethnopharmacol 2016; 190: 362-371. doi: 10.1016/j.jep.2016.06.056

Gilca M, Gaman L, Panait E, Stoian I, Atanasiu V. Chelidonium majus - an integrative review: Traditional knowledge versus modern findings. Forsch Komplementmed 2010; 17(5): 241-248. doi:10.1159/000321397

Habermehl D, Kammerer B, Handrick R, Eldh T, Gruber C, Cordes N, Daniel PT, Plasswilm L, Bamberg M, Belka C, Jendrossek V: Proapoptotic activity of Ukrain is based on Chelidonium majus $\mathrm{L}$ alkaloids and mediated via a mitochondrial death pathway. BMC Cancer 2006; 6:14. doi:10.1186/14712407-6-14

Hohenwarter O, Strutzenberger K, Katinger H, Liepins A, Nowicky JW: Selective inhibition of in vitro cell growth by the antitumor drug Ukrain. Drugs Exp Clin Res 1992; 18(suppl):1-4.

http://himedialabs.com/TD/CCK003.pdf.

Kokoska L, Polesny Z, Rada V, Nepovim A, Vanek T. Screening of some Siberian medicinal plants for antimicrobial activity. J Ethnopharmacol. 2002; 82:51-53. doi:10.1016/s0378-8741(02) 00143-5.

Lee YC, Kim SH, Roh SS, Choi HY, Seo YB. Suppressive effects of Chelidonium majus methanol extract in knee joint, regional lymph nodes, and spleen on collagen-induced arthritis in mice. $\mathrm{J}$ Ethnopharmacol. 2007; 112:408. doi: 10.1016/j.jep.2007.01.033 
Noureini SK, and Wink M: Transcriptional down regulation of hTERT and senescence induction in HepG2 cells by chelidonine. World J Gastroenterol 2009:15(29): 2603-3610. doi:10.3748/ wjg. 15.3603

Philchenkov A, Kaminsky V, Zavelevich M, Stoika R: Apoptogenic activity of two benzophenanthridine alkaloids form Chelidonium majus L. does not correlate with their DNA damaging effects. Toxicol in vitro 2008;22(2):287-295. doi: 10.1016/j.tiv.2007.08.023

Ramawat, K. G., and J. M. Merollin. Biotechnology secondary metabolites plants and microbes, $2^{\text {nd }}$ edition 2007. doi:10.1201/b10756-2

SAS, 2014. Statistical Analysis System, User's Guide. Statistical. Version 9.1th ed. SAS. Inst. Inc. Cary. N.C. USA.

Song, Jie-Young, Hyun-Ok Yang, SuhkNeung Pyo, In-Sung Jung, Seh-Yoon
Yi, and Yeon-Sook Yun. "Immunomodulatory Activity of Protein-Bound Polysaccharide Extracted from Chelidonium majus." Archives of Pharmacal Research 25, no. 2 (April 2002): 158-164. doi:10.1007/ bf02976557.

Venkatesh K, Govindaraj S, Ramachandran A, Kalimuthu S, Perumal E, Velayutham S, et al., Effect of ukrain on cell survival and apoptosis in the androgen-independent prostate cancer cell line PC-3. J Environ Pathol Toxicol Oncol. 2011; 30:11-19. doi:10.1615/jenvironpatholtoxicoloncol. v30.i1.20

Zare Shahneh F, Baradaran B, Orangi M, Zamani F. In vitro Cytotoxic Activity of Four Plants Used in Persian Traditional Medicine. Advanced Pharmaceutical Bulletin. 2013; 3(2):453-455. doi:10.5681/apb.2013.074.

\section{How to cite this article:}

Yasir B. Fadhil, Khulood W. Alsammarraie, Nedhal Abdul Mohaimen and Zainab Yasin Mohammed. 2018. In vitro Cytotoxic Activity of Chelidonium majus Extract Using Different Types of Cell Lines. Int.J.Curr.Microbiol.App.Sci. 7(01): 1767-1775. doi: https://doi.org/10.20546/ijcmas.2018.701.214 